Neurociências

\title{
Prevenção e tratamento de Hipertermia no Esporte
}

\section{Treatment and prevention of exercise hyperthermia}

\section{Antonio Carlos da Silva}

Escola Paulista de Medicina / Universidade Federal de São Paulo - UNIFESP.

A prevenção da Hipertermia em atletas portadores de deficiência pode ser um problema importante na preparação destes atletas. A utilização dos padrões gerais de prevenção contra a desidratação e o excesso de calor, com as devidas adaptações, gerou resultados satisfatórios na Equipe Paraolímpica Brasileira.

Os atletas realizaram um período de aclimatização de 12-14 dias na fase pré competição, com ajustes nas cargas de treinamento e monitoração rigorosa da FC e do peso corporal diário.

Nenhum caso de hipertermia ou desidratação aguda foi observado na competição paraolímpica.

Os mesmos princípios podem ser usados para prevenção da hipertermia em indivíduos de riscos, não atletas. 